\title{
Development of the Portuguese version of a standardized reading test: the Radner-Coimbra Charts
}

\author{
Desenvolvimento da versão portuguesa do teste padronizado de leitura: tabelas Radner-Coimbra
}

Andreia Martins Rosa ${ }^{1,2}$, Cláudia louro Farinha ${ }^{2}$, Wolfgang Radner ${ }^{3}$, Gabriela Diendorfer ${ }^{4}$, Maria Fátima Loureiro ${ }^{5}$, Joaquim Neto Murta ${ }^{1,2}$

\begin{abstract}
Purpose: To develop 27 short sentence optotypes for the Portuguese version of the Radner Reading Charts.

Methods: Thirty-four Portuguese sentences were constructed following the concept of the Radner Reading Charts to obtain highly comparable sentences in terms of lexical difficulty, syntactical complexity, word length, number of syllables, and position of words. A long text (106 words) at the $5^{\text {th }}$ grade reading level was also tested to assess the validity of the reading speeds obtained with the short sentences. The short sentences and long text were tested in 50 volunteers with similar educational backgrounds (mean age 30.98 years \pm 6.99 years, range 19-47 years). Reading speeds were measured with a stop-watch and reported as words per minute (wpm). The reading time for each of the short sentences to be selected for the chart was defined as falling within the range of the mean $\pm 0.40 \times$ standard deviation (SD).

Results: The overall mean reading speed for each of the short sentences was $235.43 \pm 36.39 \mathrm{wpm}$. The 27 sentences with a mean between 220.8 and $250.0 \mathrm{wpm}$ (overall mean $\pm 0.40 \times \mathrm{SD}$ ) were selected for construction of the reading charts. The mean reading speed for the long text was $212.42 \pm 26.20 \mathrm{wpm}$. Correlation between the selected short sentences and long text was high $(r=0.86)$. Reliability analysis yielded an overall Cronbach's alpha coefficient of 0.97 .

Conclusions: The 27 short Portuguese sentences were highly comparable in terms of syntactical structure, number, position and length of words, lexical difficulty, and reading length. This reading test can overcome the limitations of the current tests for homogeneity and comparability, reducing subjectivity in the evaluation of the functional outcomes of medical and surgical ophthalmologic treatments.
\end{abstract}

Keywords: Reading; Vision tests/methods; Visual acuity; Feasibility studies

\section{RESUMO}

Objetivo: Desenvolver 27 frases-optotipo para a versão em português das tabelas de leitura de Radner.

Métodos: Trinta e quatro frases em português foram elaboradas de acordo com o conceito das tabelas de leitura de Radner, de forma a obter frases-optotipo, altamente comparáveis em termos dificuldade lexical, complexidade sintática, tamanho das palavras, número de sílabas e posição das palavras. Foi também avaliado um texto longo (106 palavras) ao nivel do 50 ano de escolaridade para determinar a validade dos resultados obtidos com as frases curtas. As frases curtas e o texto longo foram testados em 50 voluntários de nível acadêmico semelhante e média de idades de 30,98 anos $\pm 6,99$ (intervalo de 19-47 anos). A velociade de leitura foi medida com cronômetro, de forma a obter o número de palavras por minuto (wpm). O intervalo válido para tempo de leitura das frases curtas foi definido como a média $\pm 0,40 x$ desvio padrão (SD). As frases mais semellhantes foram estatisticamente selecionadas para a construção das tabelas de leitura Radner-Coimbra.

Resultados: A velocidade média de leitura obtida com as frases curtas foi 235,43 \pm $36,39 \mathrm{wpm}$. As frases com velocidade média entre 220,8 e 250,0 palavras por minuto (média $\pm 0,40 \times S D$ ) foram selecionadas. Vinte e sete frases cumpriram este critério. A velocidade média de leitura do texto longo foi 212,42 $\pm 26,20$ wpm. A correlação entre as frases curtas selecionadas e o texto longo foi alta $(r=0,86)$. A análise de fiabilidade originou um coeficiente alfa de Cronbach de 0,97.

Conclusões: As 27 frases em português são altamente semelhantes em termos de estrutura sintática, número, posição e comprimento das palavras, dificuldade lexical e duração da leitura. Este teste permite ultrapassar as limitações dos testes existentes em termos de homogeneidade e comparabilidade, reduzindo a subjetividade na avaliação dos resultados de terapêuticas médicas e cirúrgicas.

Descritores: Leitura; Testes visuais/métodos; Estudos de viabilidade

\section{INTRODUCTION}

In modern society, the ability to read is essential for daily life. The loss of this ability has a severe impact on quality of life, with loss of independence and productivity ${ }^{(1-4)}$. There are several methods to correct presbyopia, such as reading lenses, laser treatments, and multifocal intraocular lenses. It is fundamental to have a standardized test to compare the outcomes of these options (1). Routine single optotype distance visual acuity (VA) tests have been shown to be poor predictors of reading performance and cannot elucidate the full functional impairment of several ophthalmic diseases ${ }^{(2,3,5)}$. It is therefore becoming increasingly necessary to use methods that reproducibly measure the impact of visual disabilities on the patient's everyday life and to show that the recommended therapies successfully improve quality of life ${ }^{(4,6)}$. Modern reading charts, such as the highly standardized Radner Reading Charts, allow the simultaneous evaluation of reading acuity and reading speed and thus provide more detailed information about visual impairment than traditional near vision tests (e.g., Jaeger, Nieden, Parinaud). In addition, such reading charts provide increased accuracy ${ }^{(6)}$ for the evaluation of near visual performance and have become a valuable clinical tool for pre- and postoperative assessment and for visual rehabilitation ${ }^{(7-12)}$.

International standards should be applied to the evaluation of reading performance. Bailey and Lovie described a logarithmically scaled near-vision chart and suggested that it was possible to simul-
Submitted for publication: March 27, 2015

Accepted for publication: June 9, 2016

Faculty of Medicine, Universidade de Coimbra, Portugal.

2 Centro Hospitalar e Universitário de Coimbra, Portugal.

Austrian Academy of Ophthalmology and Optometry, Austria.

${ }^{4}$ Department of Phoniatrics, Medical University of Vienna, Austria.

${ }_{5}^{5}$ Visual Neuroscience Laboratory, IBILI, Faculty of Medicine, University of Coimbra, Portugal.
Funding: No specific financial support was available for this study.

Disclosure of potential conflicts of interest: Wolfgang Radner: receives royalties for the Radner Reading Charts. The others authors have no potential conflict of interest to disclose.

Corresponding author: Joaquim Neto Murta. Centro de Responsabilidade Integrado de Oftalmologia. Centro Hospitalar e Universitário de Coimbra. Praceta Mota Pinto, 3.000 - Coimbra - Portugal E-mail: jmurta@netcabo.pt.

Approval of the research ethics committee: Faculty of Medicine of the Universidade de Coimbra (\# 025-CE-2014). 
taneously determine reading acuity and speed with single words in a row ${ }^{(13)}$. Legge et al developed the computer-based Minnesota Low-Vision Reading Test (MNread), which presents short sentences at decreasing time periods on a computer screen ${ }^{(14)}$. These sentences have then been used for the MNread cards and consist of 3 lines and 60 characters (including spaces), representing 10 standard length words of 6 characters, as given by Carver ${ }^{(15,16)}$. However, the number, length, and position of words vary considerably ${ }^{(14,17)}$.

Radner et al. emphasized the importance of sentence standardization, because sentence complexity also influences reading speed ${ }^{(4)}$. Therefore, they developed and standardized highly comparable sentences in terms of lexical difficulty, syntactical complexity, word length, number of syllables, and position of words. ${ }^{(4)}$ This concept of "sentence optotypes" results in optimally constant geometric proportions and minimal variation between the test items. High reliability and validity of the sentence optotypes as well as high test-retest and interchart reliability have been shown for Radner Reading Charts ${ }^{(4,18)}$.

A German version of Radner Reading Charts and versions in Spanish, English, French, Dutch, Danish, Swedish, Hungarian, Italian and Turkish have already been developed ${ }^{(6,19-21)}$. Other language versions are in process. Portuguese is the fifth most spoken language in the world, and the Lusophone (Portuguese-speaking) space is estimated to have approximately 241 million people ${ }^{(22)}$.

The purpose of this study was to standardize Portuguese sentence optotypes for the Portuguese version of the Radner Reading Charts (Radner-Coimbra Reading Charts), allowing the evaluation of reading parameters in Portuguese speakers, including reading acuity, reading speed, and logarithm of the minimal angle of resolution (logMAR)/logarithm of the reading acuity determination (logRAD) differences.

\section{METHODS}

\section{StUdY POPULATION}

The study population consisted of 50 native Portuguese-speaking volunteers with university education and a mean age of 30.98 years \pm 6.99 (range, 19-47 years).

Inclusion criteria were: best corrected visual acuity of 0.0 logMAR (20/20 Snellen) or better in each eye and absence of systemic and/or ocular pathology or medications that could influence the results of the study. All volunteers took the test binocularly, with near vision properly corrected if necessary. Binocular reading acuity at $40 \mathrm{~cm}$ was at least 20/20 Snellen. All tests were performed at a constant luminance of $80-90 \mathrm{~cd} / \mathrm{m}^{2}$. The study followed the tenets of the Declaration of Helsinki. An informed consent document was reviewed and signed by all volunteers.

\section{Design Of TESt SENTENCES}

The sentence optotypes (Figure 1) are relative clauses, which represent the first complex but still easy readable and commonly used adult sentences.

A total of 34 sentences were developed to be as comparable as possible in terms of grammatical difficulty as well as in number (14), length, and position of words. The sentences followed the rules that have been generated for sentence optotypes of the Radner Reading Charts, with minor language-specific modifications ${ }^{(4)}$.

\section{Measurements}

The 34 sentences were printed in 12-point Arial font, with a maximum of 8 on each page. The reading distance was $40 \mathrm{~cm}$, and luminance was $80-90 \mathrm{~cd} / \mathrm{m}^{2}$. The sentences were covered with a blank piece of paper, and the volunteers were asked to uncover the sentences sequentially, reading each one aloud as quickly and accurately as possible. They were advised not to stop or repeat part of the sentence to correct mistakes. The procedure was the same for all sentences.

\section{Os clientes escolhem as cores de catálogos, que tinham sido levados pelos novos pintores}

\section{As escadas do hospital estão a escorregar, porque foram já lavadas pela nova empregada}

\author{
A menina passeia pelas ruas \\ na bicicleta rosa, que tinha \\ recebido com muita satisfação
}

Figure 1. Sample sentences from the 34 sentence optotypes developed and tested for the Radner-Coimbra Chart.

Reading time was measured with a stopwatch. Reading speed in words per minute (wpm) was calculated on the basis of the number of words in a sentence ( 14 words) and the time needed to read the sentence ( 14 words $\times 60$ seconds divided by the reading time). Reading errors were noted by marking the wrong words in the sentence on a study form. Errors were counted even when immediately corrected. The criterion for selection of sentences for the chart was a reading time within the range defined by the overall mean reading time for each of the sentences $\pm 0.40 \times \mathrm{SD}$ (standard deviation). A longer text of 106 words ("A Fada Oriana") at the $5^{\text {th }}$ grade reading level (ie, for 10-year-old school children) was tested for reading speed to assess the validity of the results obtained with the short sentences. The main outcome measures were reading time and number of mistakes for each sentence.

\section{Statistical analysis}

Statistical analyses were performed using SPSS for Windows (version 19.0, SPSS, Inc.). The mean \pm SD of both the reading time and number of mistakes made in each sentence were calculated. The data showed a fairly symmetric unimodal distribution, so that the assumption of a normal distribution for the mean, as required for the t test, was justified (Kolmogorov-Smirnov). Correlation analyses were performed using Pearson correlation. The cut-off level for statistical significance was set at $P<0.01$, two-tailed.

\section{RESULTS}

The mean reading speed for all sentences was $235.43 \pm 36.39 \mathrm{wpm}$ (range, 126.5 to 389.6). The mean reading time per sentence was 3.66 \pm 0.59 seconds (sec). To be selected for the reading charts, the mean time to read a sentence optotype had to be within the range of 3.42 to $3.89 \mathrm{sec}$ (range calculated as $3.66 \pm 0.4 \times \mathrm{SD}$ ), with a reading speed between 220.8 to $250.0 \mathrm{wpm}$ (range calculated as $235.43 \pm 0.4 \times$ SD). Of the 34 sentences tested, 27 met the reading time and speed criteria. Seven sentences (numbers 9, 13, 19, 27, 28, 33, and 34) were excluded because they were outside the prescribed range. Figure 2 shows the mean reading time for each sentence.

The mean number of reading mistakes for all sentences was $0.13 \pm$ 0.37 words/sentence (Figure 3). The mean number of reading mistakes for the long text was $0.80 \pm 0.99$ words/sentence.

To assess the validity of the reading speed measurements obtained with our short sentences, we compared these reading speed results to those obtained with the long text (Figure 4). The mean reading speed 


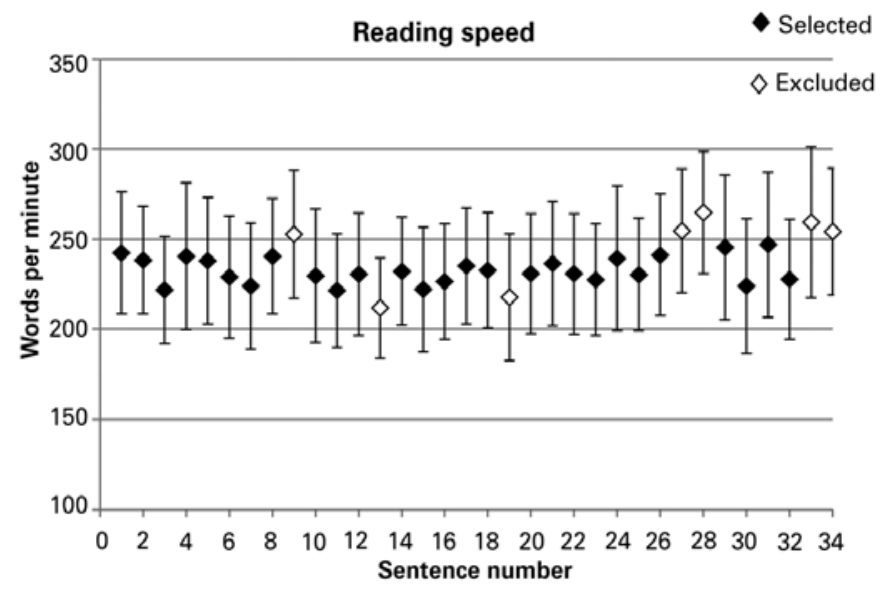

Figure 2. Mean reading speed and standard deviation for 34 sentence optotypes (overall mean reading speed: $235.43 \pm 36.39 \mathrm{wpm}$ ). Black diamonds represent the sentences selected for the Radner-Coimbra Chart; white diamonds represent excluded sentences.

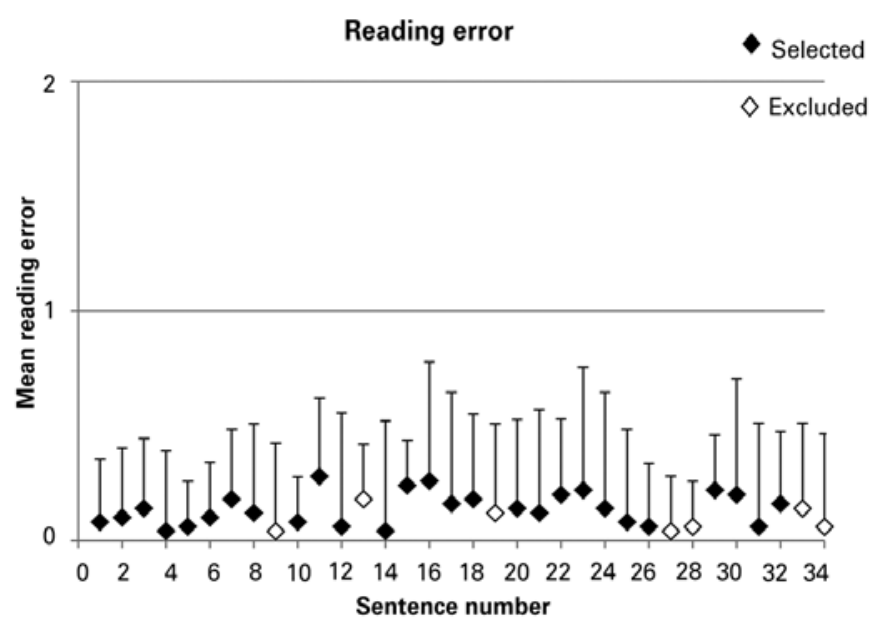

Figure 3. Mean error number and standard deviation for the 34 sentence optotypes. The mean number of reading errors was $0.13 \pm 0.37$ errors. Black diamonds represent the sentences selected for the Radner-Coimbra Chart; white diamonds represent excluded sentences.

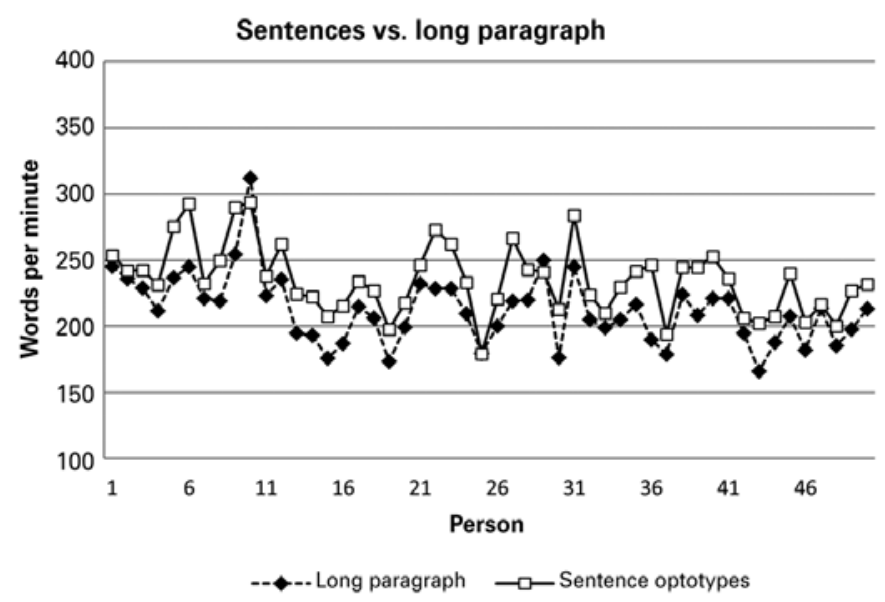

Figure 4. Reading speeds of 50 readers, comparing reading of a long paragraph (106 words; diamonds) vs. sentence optotypes (squares). for the long text was $212.42 \pm 26.20$ wpm. This was lower than that for the short sentences, but the correlation between the two methods was high ( $r=0.86, p<0.001)$, thus confirming the validity of the results obtained with the short sentences.

The reliability analysis for reading speed results for the short sentence optotypes yielded an overall Cronbach's alpha coefficient of 0.98 for all 34 sentences and 0.97 for the 27 selected sentences. The coefficient of reliability for each of the 27 sentence optotypes varied from 0.62 to 0.89 .

\section{DISCUSSION}

Reading is a complex task that involves not only visual sensorial input but also accurate eye movements and cognitive capacity ${ }^{(23)}$. Therefore, reading tests are not only different from distance acuity tests but also differ from near acuity tests using single optotypes ${ }^{(24)}$. LogMAR defines the minimal angle at which two points can be recognized as being two. Although angular resolution is a key factor in reading acuity, it is not what is evaluated when reading ability is examined. LogRAD is the reading equivalent of logMAR. For a more differentiated documentation of reading acuity, the use of logRAD is preferred. LogMAR should be used exclusively for single-optotype visual acuity testing ${ }^{(7)}$.

A reading speed below 80 wpm has been found to be the lower limit for recreational, sense-capturing reading performance ${ }^{(25,26)}$. In addition, because normal newspaper print size varies from 10 to 12 points, a reading acuity of at least 0.4 logRAD is a basic requirement for reasonable reading performance ${ }^{(26)}$. A recent review of the measurement properties of reading acuity tests identified 2334 articles $^{(24)}$. Of these 2334, only 20 articles had information concerning the measurement properties of the tests. Of particular note, only three reading tests, IReST, MNRead, and Radner Reading Charts, were included in these assessments ${ }^{(24)}$. Both the MNRead chart and the Radner Reading Charts meet the requirements of a logarithmically progressing print size from one sentence to another and the possibility of measuring reading speed (in wpm) and reading acuity simultaneously. The original Radner Reading Charts in German are different from other performance-reading charts like the MNRead, because Radner et al. developed the concept of sentence optotypes ${ }^{(4)}$. The MNRead used sentences that were only similar in number of lines and number of characters, not in the length and position of words. Because sentence complexity also influences reading speed, Radner et al. ${ }^{(4,20)}$ focused also in the importance of sentence standardization. They therefore developed and standardized highly comparable sentences in terms of lexical difficulty, syntactical complexity, word length, and number of syllables, thus establishing sentence optotypes. This principle makes these charts superior, more reliable, and easier to standardize $\mathrm{e}^{(3,14,19)}$. Radner and his co-workers also demonstrated that the Radner Reading Charts with highly comparable and standardized sentence optotypes could provide reliable, reproducible and comparable measurements of reading performance for both clinical practice and scientific investigation ${ }^{(4,20)}$. They also have shown that these charts provide highly reproducible measurements of reading acuity and speed in individuals with either no or varying degrees of visual impairment. In fact, Radner Reading Charts have been successfully used in cases with a variety of ocular pathology (e.g., cataract, macular disease, amblyopia) ${ }^{(2,5,12,18)}$.

The Radner Reading Charts have been developed in several languages (e.g., German, Dutch, English, French, Spanish, Danish, Hungarian, Italian, Swedish, and Turkish). However, the original German sentences cannot be literally translated. New sentence optotypes have to be composed and tested for reliability with specific modifications to fit each particular language. Similar to other language versions which are less related to German, such as the Spanish or Italian versions, the sentence criteria for the Portuguese version had to be modified also, reflecting the typical characteristics of our 
$\log R A D$

TABELAS DE LEITURA

Visus

Snellen

$40 \mathrm{~cm} / 32 \mathrm{~cm}$

RADNER - COIMBRA 1

$40 \mathrm{~cm} / 32 \mathrm{~cm} \quad 40 \mathrm{~cm} / 32 \mathrm{~cm}$

\section{Eu queria castigar quem fez}

$0.9 /, 0$ as calúnias, que causaram à $0.125 /, 10 \frac{20}{150 / 20}$ cantora tão grandes tristezas

\section{Os clientes escolhem as cores}

$0,8,0,9$ de catálogos, que tinham sido

$0,16 / 0,125 \quad \frac{20}{125} / \frac{20}{150}$ levados pelos novos pintores

As médicas discutem os dados

$0,7 / 0,8$ de pacientes, que tinham sido atendidos por outros colegas

As escadas do hospital estão

$0,6 / 0,7$ a escorregar, porque foram já lavadas pela nova empregada

A criança suspeita onde está a bicicleta, que tinha sido escondida na noite anterior

Valores de correçăo em funçăo da distância:

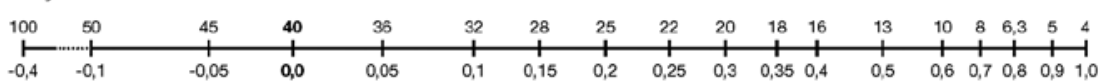


language with regard to lexical difficulty, syntactical complexity, word length, number of syllables, and position of words. Therefore, it is important for every language to test the reliability of the Radner Reading Charts, as has been stated in other studies ${ }^{(6,20,21)}$. Although there are important dissimilarities within a language group in the way people speak the same language, written Portuguese has fewer differences. Words are essentially the same and can be read by people from different Portuguese-speaking countries, as is true for the English and Spanish versions. Furthermore, the instructions that come with the test explain that each sentence should be read word by word, so that it becomes less important if the subject performing the test would choose to say the sentence in a different way.

The sentences were created as consistently as possible, following highly defined rules, including the same number of words (14), same word length, and same word position. The typical word length and word distribution of the Portuguese language was taken into consideration. The length of a line was chosen to be between 27 and 29 characters, as in other Radner Reading Charts, because this number is used in many newspaper columns ${ }^{(4)}$. To define a set of comparable sentences as test items for the reading charts, we selected from among the initial 34 sentences the 27 with the most equivalent results. The validity of reading speed measurements obtained with the short sentences was found to correlate well with the reading speeds obtained with a long text. For example, subjects reading the long text slower also read the short sentences slower.

The test psychology and the psychological backgrounds behind the Portuguese version follow the ones originally applied in the German version. The principles and methods for sentence selection remain consistent between all languages.

Thus, reading speed measurements with our 27 short Portuguese sentence optotypes provided a valid measure of reading performance. These 27 sentences optotypes were then used for the development of the Portuguese version of the Radner Reading Charts.

In the Radner-Coimbra Reading Charts, the standardized sentence optotypes are presented in logarithmical scaling (logRAD format) in accordance with international standards in order to maintain constant geometrical proportion at all distances and limit changes in reading speed mainly to the print size (Figure 5).

In conclusion, a new version of the Radner Reading Charts in Portuguese (Radner-Coimbra Charts) was developed. The development of standardized reading charts in Portuguese for the simultaneous determination of reading acuity and reading speed in the same examination is a refinement in the diagnosis of reading performance in Portuguese speaking patients, allowing adherence to international standards for clinical research and potentially improving diagnosis in daily practice.

\section{REFERENCES}

1. Rosa AM, Loureiro Silva MF, Lobo C, Mira JB, Farinha CL, Povoa JA, et al. Comparison of visual function after bilateral implantation of inferior sector-shaped near-addition and diffractive-refractive multifocal IOLs. J Cataract Refract Surg. 2013;39(11):1653-9.
2. Elliott DB, Hurst MA, Weatherill J. Comparing clinical tests of visual function in cataract with the patient's perceived visual disability. Eye (Lond). 1990;4(Pt 5):712-7.

3. Legge GE, Ross JA, Isenberg LM, LaMay JM. Psychophysics of reading. Clinical predictors of low-vision reading speed. Invest Ophthalmol Vis Sci. 1992;33(3):677-87.

4. Radner W, Obermayer W, Richter-Mueksch S, Willinger U, Velikay-Parel M, Eisenwort B. The validity and reliability of short German sentences for measuring reading speed. Graefes Arch Clin Exp Ophthalmol. 2002;240(6):461-7.

5. Richter-Mueksch S, Stur M, Stifter E, Radner W. Differences in reading performance of patients with Drusen maculopathy and subretinal fibrosis after CNV. Graefes Arch Clin Exp Ophthalmol. 2006;244(2):154-62.

6. Alio JL, Radner W, Plaza-Puche AB, Ortiz D, Neipp MC, Quiles MJ, et al. Design of short Spanish sentences for measuring reading performance: Radner-Vissum test. J Cataract Refract Surg. 2008;34(4):638-42.

7. Richter-Mueksch S, Weghaupt H, Skorpik C, Velikay-Parel M, Radner W. Reading performance with a refractive multifocal and a diffractive bifocal intraocular lens. J Cataract Refract Surg. 2002;28(11):1957-63.

8. Burggraaff MC, van Nispen RM, Hoek S, Knol DL, van Rens GH. Feasibility of the Radner Reading Charts in low-vision patients. Graefes Arch Clin Exp Ophthalmol. 2010; 248(11):1631-7.

9. Richter-Mueksch S, Kaminski S, Kuchar A, Stifter E, Velikay-Parel M, Radner W. Influence of laser in situ keratomileusis and laser epithelial keratectomy on patients' reading performance. J Cataract Refract Surg. 2005;31(8):1544-8.

10. Hutz WW, Eckhardt HB, Rohrig B, Grolmus R. Reading ability with 3 multifocal intraocular lens models. J Cataract Refract Surg. 2006;32(12):2015-21.

11. Stifter E, Burggasser G, Hirmann E, Thaler A, Radner W. Evaluating reading acuity and speed in children with microstrabismic amblyopia using a standardized reading chart system. Graefes Arch Clin Exp Ophthalmol. 2005;243(12):1228-35.

12. Stifter E, Weghaupt H, Benesch T, Thaler A, Radner W. Discriminative power of reading tests to differentiate visual impairment caused by cataract and age-related macular degeneration. J Cataract Refract Surg. 2005;31(11):2111-9.

13. Bailey IL, Lovie JE. The design and use of a new near-vision chart. Am J Optom Physiol Opt. 1980;57(6):378-87

14. Legge GE, Ross JA, Luebker A, LaMay JM. Psychophysics of reading. VIII. The Minnesota Low-Vision Reading Test. Optom Vis Sci. 1989;66(12):843-53.

15. Carver RP. Reading rate: a review of research and theory. San Diego: Academic Press; 1990.

16. Castro CT, Kallie CS, Salomao SR. [Development and validation of the MNREAD reading acuity chart in Portuguese]. Arq Bras Oftalmol. 2005;68(6):777-83. Portuguese.

17. Messias A, Velasco e Cruz AA, Schallenmuller SJ, Trauzettel-Klosinski S. [New standardized texts in Brazilian Portuguese to assess reading speed--comparison with four European languages]. Arq Bras Oftalmol. 2008;71(4):553-8. Portuguese

18. Stifter E, Konig F, Lang T, Bauer P, Richter-Muksch S, Velikay-Parel M, et al. Reliability of a standardized reading chart system: variance component analysis, test-retest and inter-chart reliability. Graefes Arch Clin Exp Ophthalmol. 2004;242(1):31-9.

19. Maaijwee K, Mulder P, Radner W, Van Meurs JC. Reliability testing of the Dutch version of the Radner Reading Charts. Optom Vis Sci. 2008:85(5):353-8.

20. Radner W, Diendorfer G. English sentence optotypes for measuring reading acuity and speed--the English version of the Radner Reading Charts. Graefes Arch Clin Exp Ophthalmol. 2014:252(8):1297-303.

21. Calossi A, Boccardo L, Fossetti A, Radner W. Design of short Italian sentences to assess near vision performance. J Optom. 2014;7(4):203-9.

22. Utah TUo. Portuguese \& Brazilian Studies 2015 [20th March 2015].

23. Latham K, Whitaker D. A comparison of word recognition and reading performance in foveal and peripheral vision. Vision Res. 1996;36(17):2665-74.

24. Brussee T, van Nispen RM, van Rens GH. Measurement properties of continuous text reading performance tests. Ophthalmic Physiol Opt. 2014;34(6):636-57.

25. Rubin GS, West SK, Munoz B, Bandeen-Roche K, Zeger S, Schein O, et al. A comprehensive assessment of visual impairment in a population of older Americans. The SEE Study. Salisbury Eye Evaluation Project. Invest Ophthalmol Vis Sci. 1997;38(3):557-68.

26. West SK, Munoz B, Rubin GS, Schein OD, Bandeen-Roche K, Zeger S, et al. Function and visual impairment in a population-based study of older adults. The SEE project. Salisbury Eye Evaluation. Invest Ophthalmol Vis Sci. 1997;38(1):72-82. 